\title{
Chemical composition and SDS-PAGE analysis of radiated, extruded and sprouted soybean
}

\author{
Mehdi Moghaddam ${ }^{1}$, Parvin Shawrang ${ }^{2}$, Ali Asghar Sadeghi ${ }^{1 *}$ and Mohammad Chamani ${ }^{1}$ \\ ${ }^{1}$ Department of Animal Science, Science and Research Branch, Islamic Azad University, Tehran, Iran \\ ${ }^{2}$ Nuclear Science and Technology Research Institute, Atomic Energy Organization, Karaj, Iran
}

\section{Article history}

Received: 01 Sep, 2015

Revised: 10 Nov, 2015

Accepted: 08 Dec, 2015

\begin{abstract}
The aim of the present study was to examine the effects of gamma irradiation and extrusion on chemical composition and protein subunit patterns of soybean (SB), sprouted soybean (SSB) and extruded soybean (EBM) using SDS-PAGE electrophoresis. Part of the soybeans was germinated in 3 days in a pollution-free environment. After extracting fat, samples were poured in extraction solution and stored at temperature of $-20^{\circ} \mathrm{C}$ for electrophoresis. Ash decreased significantly $(\mathrm{P}<0.05)$ in soybean meal radiated with $45 \mathrm{kGy}$. Ether extract $(\mathrm{EE})$ was reduced significantly $(\mathrm{P}<0.05)$ in soybean meal irradiated with $15 \mathrm{kGy}$ and sprouted soybean irradiated with dose $15 \mathrm{kGy}$. Neutral detergent fibre (NDF) decreased significantly $(\mathrm{P}<0.05)$ in soybean irradiated with dose $30 \mathrm{kGy}$ and soybean meal irradiated with dose $30 \mathrm{kGy}$. Acid detergent fibre $(\mathrm{ADF})$ decreased significantly $(\mathrm{P}<0.05)$ in soybean irradiated with dose $30 \mathrm{kGy}$ and $45 \mathrm{kGy}$. Acid detergent lignin (ADL) decreased significantly $(\mathrm{P}<0.05)$ in soybean irradiated with dose $45 \mathrm{kGy}$ and extruded sprouted soybean. Regarding SDS-PAGE electrophoresis results, SB, SSB and EBM proteins were mainly composed of two major polypeptides including Glycinin and $\beta$ Conglycinin and the subunit molecular weights (MWs) were affected by the processing. The results of the study showed that the extrusion had the greatest impact On reducing Glycinin subunits and dose of 15 and $45 \mathrm{kGy}$ of the gamma irradiation reduced and increased MWs of the protein subunits, respectively. Gamma irradiation cross-linking the subunit of proteins which this characterize can be a good substitute for SB, SSB and EBM digestion and absorption

Keywords: Extruding; gamma; molecular weights; sprout
\end{abstract}

To cite this article: Moghaddam M, P Shawrang, AA Sadeghi and M Chamani, 2016. Chemical composition and SDS-PAGE analysis of radiated, extruded and sprouted soybean. Res. Opin. Anim. Vet. Sci., 6(3): $101-107$.

\section{Introduction}

Soybean meal is considered as a common protein resource for poultry nutrition, which is well used by poultry, especially broilers. Among oilseed meal, soybean meal is the most widely used in poultry feed.
By analyzing the amino acid content of soybean meal, its importance is well recognized in mixed rations. The soybean meal is delicious and has a good balance of amino acids with high availability (Sadeghi et al., 2006).

The irradiated feed is used in animal nutrition with the aim of improving the nutritional value in terms of

\footnotetext{
*Corresponding author: Ali Asghar Sadeghi, Department of Animal Science, Science and Research Branch, Islamic Azad University, Tehran, Iran
} 
the quality of protein and starch and removing antinutritional factors and microbial contamination (Variyar et al., 2004). Gamma irradiation causes the depolymerization of complex compounds through the production of ions and free radicals. The electrophoresis of protein of irradiated soybean showed that low dose of gamma-ray causes the reduction of the hybrid power, a minor fracture in the polypeptide chain, and the formation of molecules with a low molecular weight (Davies, 1998). Extrusion has been found useful in poultry feed (Oryschak et al., 2010). Extrusion is a hydrothermal process which uses combinations of pressure, moisture, temperature and mixing with variable time to improve the physical and the nutrient structure of diets and ingredients (Fallahi et al., 2013). Ayadi et al. (2011) stated the advantages of extrusion are reduced anti-nutritional factors, improved palatability, and digestibility. Oryschak et al. (2010) reported that extrusion significantly improved amino acid digestibility in poultry.

The vertical electrophoresis of sodium dodecyl sulfate polyacrylamide gel electrophoresis (SDSPAGE) is used to determine the pattern of protein subunits. The PAGE is the most useful techniques for determining the purity of proteins in biological samples and molecular weight (MW) of polypeptide chains. The basis of this method is the movement of the charged molecules in an electric field in which the speed of the molecules is determined by MWs. So, the aim of this study was to investigate the effects of gamma irradiation, extrusion and sprouting on chemical composition and the SDS-PAGE pattern of soybean (SB), sprouted soybean (SSB) and extruded soybean (EBM). It is essential to determine the appropriate dose of radiation of food in order to optimize the improvement of the quality of protein.

\section{Materials and Methods}

\section{Sample preparation, irradiation, extrusion and sprouting}

One of the most commonly used cultivars of SB and EBM in Iran, was provided by the Oilseed Factory, Tehran, Iran. The whole fat-free samples used in this study were assayed at 959 and $896 \mathrm{~g} \mathrm{DM} / \mathrm{kg}$ for SB and EBM, respectively. This value was determined by oven drying a $1 \mathrm{~g}$ sample in duplicate prior to processing. A part of the soybeans was spread on a newspaper for 3 days for germination. After 3 days of germination, they were collected and dried. Then these samples were divided into twelve equal portions and placed in paper packages. Three paper packages of each sample were irradiated in a gamma cell for average doses of 15, 30 and $45 \mathrm{kGy}$. One package was placed at a room temperature to be used as a control. After completing the irradiation, the samples were collected and stored in plastic bags for the experiment. Gamma irradiation was carried out in the Radiation Applications Research School, Atomic Energy Organization of Iran by a Gamma-Cell (Co-60), and GC-220 (AECL, 1984). The dose rate determined by Fricke dosimetry was 2.48 Gy/s (Taghinejad et al., 2009). Also, one part of the feed was processed by extrusion at the temperature of $130^{\circ} \mathrm{C}$ and under pressure (45 otmosphere) and humidity $(20-30 \%)$. It was removed from the device within 10-15 seconds.

\section{Protein monitoring subunits pattern}

Protein subunits were fractionated by the SDSPAGE technique according to the Laemmli method as described by Sadeghi and Shawrang (2008) using Vertical Slab Unit (MOD: VSS1100 double gel with cooling chamber, Akhtarian, Iran). Briefly, $0.015 \mathrm{~g}$ of dried raw or processed treatment was placed into $750 \mu \mathrm{l}$ of SDS-PAGE sample buffer. After 30 min of thorough mixing (inverse and vortex), treatments were immersed at $100{ }^{\circ} \mathrm{C}$ for $3 \mathrm{~min}$ and centrifuged at $10,000 \times \mathrm{g}$ for 2 min, and $25 \mu \mathrm{l}$ of each sample was then loaded into the sample cell of gel. Electrophoresis of proteins was performed on $12 \%$ resolving gel $(1.0 \mathrm{~mm} \times 110 \mathrm{~mm} \times$ $140 \mathrm{~mm}$ ) with $1.95 \%$ acrylamide stacking gel. The gels were kept at a constant current of $30 \mathrm{~mA}$ and variable voltage until the Bromo Phenol Blue marker dye reached the bottom of the gel. Protein fixation and staining were completed simultaneously using a solution of Coomassie Brilliant Blue. The gel destaining was done by using a $300 \mathrm{ml} / \mathrm{l}$ methanol and $70 \mathrm{ml} / \mathrm{l}$ acetic acid solution (Taghinejad-Roudbaneh et al., 2010).

\section{Chemical analyses}

Dry matter, ash, ether extract and crude protein were determined by the method of AOAC (2000). Crude fiber (CF), neutral detergent fiber (NDF) and acid detergent fiber (ADF) were determined according to Van Soest (1991).

\section{Statistical analysis}

Data analysis was performed by using the general linear model procedure and the comparison of means was made through Duncan's (1995) multiple range tests by using SAS 9.3 software (SAS, 2004).

\section{Results}

Ash decreased significantly $(\mathrm{P}<0.05)$ in soybean meal radiated with $45 \mathrm{kGy}$. Ether extract (EE) reduced significantly $(\mathrm{P}<0.05)$ in soybean meal irradiated with $15 \mathrm{kGy}$ and sprouted soybean irradiated with dose 15 kGy. Neutral detergent fibre (NDF) decreased significantly $(\mathrm{P}<0.05)$ in soybean irradiated with dose $30 \mathrm{kGy}$ and soybean meal irradiated with dose $30 \mathrm{kGy}$. Acid detergent fibre (ADF) decreased significantly 
$(\mathrm{P}<0.05)$ in soybean irradiated with dose $30 \mathrm{kGy}$ and 45 kGy. Acid detergent lignin (ADL) decreased significantly $(\mathrm{P}<0.05)$ in soybean irradiated with dose of $45 \mathrm{kGy}$ and extruded sprouted soybean.

The effects of gamma-ray irradiation and extrusion on the SB protein subunits monitored by electrophoresis technique are shown in Fig. 1. On top of the running gel, protein bands were narrow in the raw and extruded samples that estimate the MWs of SB protein subunits shown in Table 2. Treatments A (' $\alpha$ and $\beta), C(\alpha), B$ and $\mathrm{D}$ (Acidic), and C and D (Basic) were primarily composed of $\beta$-conglycinin and glycinin, that have the lowest MWs of protein subunits. Also, treatments E (' $\alpha, \alpha$ and $\beta$ ) and A (Acidic and Basic) were primarily composed of $\beta$-conglycinin and glycinin having the highest MWs of protein subunits.

The SDS-PAGE analysis of SSB protein subunits is presented in Fig 1 . Treatment $\mathrm{H}$ was primarily composed of $\beta$-conglycinin ( $\alpha=61.2 \mathrm{kDa} ; \alpha=52.9 \mathrm{kDa}$; $\beta=40.0 \mathrm{kDa}$ ) and treatment $\mathrm{G}$ was primarily composed of glycinin $(\mathrm{A}=23.6 \mathrm{kDa} ; \mathrm{B}=17.3 \mathrm{kDa})$, that have the lowest MWs of protein subunits. The electrophoretic patterns of untreated, extruded, 15, 30 and $45 \mathrm{kGy}$ irradiated SSB proteins are provided in Table 2. Treatment $\mathbf{J}$ was primarily composed of $\beta$-conglycinin and glycinin that have the highest MWs of protein subunits.

The irradiation with a dose of $15 \mathrm{kGy}$ of gammaray reduced MWs of protein subunits more than the other doses and the extrusion. Also, the dose of $30 \mathrm{kGy}$ of gamma-ray had almost similar effects on MWs with extrusion in MWs of protein subunits and their values of MWs are almost consistent with the values of the control. However, the dose of $45 \mathrm{kGy}$ increased MWs of protein subunits. In most cases, sprouting of soybean seeds increased MWs of protein subunits. This increase was observed in control and processed treatments (Table 2).

There were few differences in band patterns and intensities of irradiated, extruded and control treatments. Fig 1 shows the SDS-PAGE profile of the protein subunits pattern of untreated and treated EBM. The $\alpha^{\prime}, \alpha$ and $\beta$ subunits of $\beta$-conglycinin, and Acidic and Basic protein subunits of glycinin for untreated EBM showed the highest MWs which might have reduced the glycinin digestibility (Table 2). The $\alpha^{\prime}$ and $\alpha$ subunits of $\beta$-conglycinin and Acidic and Basic subunits of glycinin from irradiated EBM with $45 \mathrm{kGy}$ of gamma ray have the lowest protein subunits MWs probably leading to increased digestibility of $\beta$ conglycinin and glycinin. The $\beta$ subunits of $\beta$-conglycinin of irradiated EBM with $15 \mathrm{kGy}$ of gamma ray EBM had lower protein subunits MWs compared to the control.

\section{Discussion}

No significant change in the chemical composition $(\mathrm{CP}$ and $\mathrm{DM})$ of the processed treatments is in agreement with previous works (Kjaer and Hansen, 2007; Shawrang et al., 2011), in which no effect of gamma irradiation and extrusion on chemical composition of treatments was found.

Table 1: Chemical composition of SB, SSB and EBM (\%DM)

\begin{tabular}{|c|c|c|c|c|c|c|c|c|c|}
\hline Treatment & DM & $\mathrm{OM}$ & Ash & $\mathrm{CP}$ & EE & $\mathrm{CF}$ & NDF & ADF & ADL \\
\hline A & 0.959 & 0.895 & $0.057^{\mathrm{ab}}$ & 37.720 & $0.164^{\mathrm{a}}$ & $7.800^{\mathrm{ab}}$ & $15.200^{\mathrm{b}}$ & $8.200^{b}$ & $0.766^{\mathrm{bc}}$ \\
\hline B & 0.961 & 0.898 & $0.063^{\mathrm{a}}$ & 40.440 & $0.158^{\mathrm{ab}}$ & $7.00^{\mathrm{bc}}$ & $24.400^{\mathrm{a}}$ & $13.200^{\mathrm{a}}$ & $2.400^{\mathrm{a}}$ \\
\hline $\mathrm{C}$ & 0.947 & 0.894 & $0.053^{\mathrm{b}}$ & 37.937 & $0.123^{\mathrm{c}}$ & $8.400^{\mathrm{a}}$ & $14.400^{\mathrm{b}}$ & $8.000^{\mathrm{b}}$ & $1.000^{\mathrm{b}}$ \\
\hline D & 0.949 & 0.895 & $0.054^{\mathrm{ab}}$ & 38.113 & $0.146^{\mathrm{b}}$ & $7.00^{\mathrm{bc}}$ & $11.766^{\mathrm{c}}$ & $5.766^{\mathrm{c}}$ & $0.600^{\mathrm{bc}}$ \\
\hline $\mathrm{E}$ & 0.948 & 0.896 & $0.051^{\mathrm{b}}$ & 38.502 & $0.154^{\mathrm{ab}}$ & $6.200^{c}$ & $10.600^{\mathrm{d}}$ & $5.400^{\mathrm{c}}$ & $0.200^{\mathrm{c}}$ \\
\hline SEM & 0.0664 & 0.0057 & 0.0048 & 3.3170 & 0.0064 & 0.5458 & 0.5501 & 0.5046 & 0.3109 \\
\hline $\mathrm{F}$ & 0.938 & 0.887 & 0.051 & 40.622 & $0.214^{\mathrm{a}}$ & $11.400^{\mathrm{a}}$ & $21.000^{\mathrm{a}}$ & $10.000^{\mathrm{a}}$ & $5.000^{\mathrm{a}}$ \\
\hline G & 0.944 & 0.889 & 0.055 & 43.273 & $0.157^{\mathrm{b}}$ & $6.400^{\mathrm{b}}$ & $20.600^{\mathrm{a}}$ & $6.860^{\mathrm{b}}$ & $0.860^{\mathrm{c}}$ \\
\hline $\mathrm{H}$ & 0.938 & 0.888 & 0.051 & 40.870 & $0.108^{c}$ & $11.600^{\mathrm{a}}$ & $21.600^{\mathrm{a}}$ & $11.766^{\mathrm{a}}$ & $3.400^{\mathrm{b}}$ \\
\hline I & 0.939 & 0.883 & 0.056 & 41.294 & $0.158^{\mathrm{b}}$ & $11.000^{\mathrm{a}}$ & $20.400^{\mathrm{a}}$ & $11.600^{\mathrm{a}}$ & $3.800^{\mathrm{b}}$ \\
\hline $\mathrm{J}$ & 0.937 & 0.887 & 0.050 & 41.400 & $0.165^{\mathrm{b}}$ & $10.000^{\mathrm{a}}$ & $13.466^{\mathrm{b}}$ & $6.800^{\mathrm{b}}$ & $3.800^{\mathrm{b}}$ \\
\hline SEM & 0.1149 & 0.0822 & 0.0075 & 2.0493 & 0.0042 & 1.214 & 0.9490 & 0.9784 & 0.5000 \\
\hline $\mathrm{K}$ & 0.896 & 0.835 & 0.060 & 48.570 & $0.164^{b}$ & $5.800^{\mathrm{ab}}$ & $20.600^{\mathrm{a}}$ & $7.430^{\mathrm{ab}}$ & $0.290^{\mathrm{b}}$ \\
\hline $\mathrm{L}$ & 0.891 & 0.828 & 0.062 & 49.920 & $0.147^{\mathrm{b}}$ & $5.600^{\mathrm{ab}}$ & $20.600^{\mathrm{a}}$ & $6.570^{\mathrm{ab}}$ & $0.290^{\mathrm{b}}$ \\
\hline M & 0.908 & 0.849 & 0.058 & 49.350 & $0.292^{\mathrm{a}}$ & $6.200^{\mathrm{a}}$ & $14.033^{\mathrm{b}}$ & $6.860^{\mathrm{ab}}$ & $0.290^{\mathrm{b}}$ \\
\hline $\mathrm{N}$ & 0.906 & 0.844 & 0.062 & 49.033 & $0.273^{\mathrm{a}}$ & $5.600^{\mathrm{ab}}$ & $12.300^{\mathrm{c}}$ & $6.000^{\mathrm{b}}$ & $0.290^{\mathrm{b}}$ \\
\hline $\mathrm{O}$ & 0.905 & 0.844 & 0.060 & 49.599 & $0.255^{\mathrm{a}}$ & $5.000^{\mathrm{b}}$ & $13.000^{\mathrm{bc}}$ & $8.000^{\mathrm{a}}$ & $1.330^{\mathrm{a}}$ \\
\hline SEM & 0.0685 & 0.0663 & 0.0149 & 1.1832 & 0.0233 & 0.5495 & 0.7474 & 0.7603 & 0.1725 \\
\hline
\end{tabular}

$\mathrm{DM}=$ dry matter, $\mathrm{OM}=$ organic matter, $\mathrm{CP}=$ crude protein, $\mathrm{EE}=$ ether extract, $\mathrm{CF}=$ crude fiber, $\mathrm{NDF}=$ neutral detergent fiber, $\mathrm{ADF}=$ acid detergent fiber, $\mathrm{ADL}=$ acid detergent lignin, $\mathrm{SEM}=$ standard error of the mean. Means in the same column bear same superscripts do not significantly differ (P>0.05); A: Soybean, B: Extruded soybean, C: Soybean irradiated with dose 15 kGy, D: Soybean irradiated with dose $30 \mathrm{kGy}$, E: Soybean irradiated with dose 45 kGy, F: Sprouted soybean, G: Extruded sprouted soybean, H: Sprouted soybean irradiated with dose $15 \mathrm{kGy}$, I: Sprouted soybean irradiated with dose $30 \mathrm{kGy}$, J: Sprouted soybean irradiated with dose $45 \mathrm{kGy}$, K: Soybean meal, L: Extruded soybean meal, M: Soybean meal irradiated with dose 15 kGy, N: Soybean meal irradiated with dose $30 \mathrm{kGy}$, O: Soybean meal irradiated with dose $45 \mathrm{kGy}$. 
Res. Opin. Anim. Vet. Sci., 2016, 6(3): 101-107.

Table 2: Estimated MWs of SB, SSB and EBM protein subunits

\begin{tabular}{|c|c|c|c|c|c|c|c|c|c|c|c|c|c|c|c|c|}
\hline Protein & Subunit & $\mathrm{A}$ & B & $\mathrm{C}$ & $\mathrm{D}$ & $\mathrm{E}$ & $\mathrm{F}$ & $\mathrm{G}$ & $\mathrm{H}$ & I & $\mathrm{J}$ & $\mathrm{K}$ & $\mathrm{L}$ & $\mathrm{M}$ & $\mathrm{N}$ & $\mathrm{O}$ \\
\hline$\beta-$ & $\alpha$ & 59.0 & 60.5 & 59.8 & 60.5 & 64.5 & 65.0 & 63.4 & 61.2 & 63.4 & 68.9 & 57.2 & 56.6 & 54.9 & 54.4 & 50.4 \\
\hline \multirow{2}{*}{ conglycinin } & $\alpha$ & 50.0 & 49.8 & 49.5 & 51.1 & 55.5 & 57.0 & 55.1 & 53.9 & 56.4 & 60.5 & 49.9 & 49.9 & 49.3 & 49.6 & 49.0 \\
\hline & $\beta$ & 39.9 & 40.8 & 40.4 & 40.6 & 42.6 & 41.2 & 41.0 & 40.0 & 41.4 & 42.6 & 40.0 & 39.3 & 37.8 & 38.5 & 39.7 \\
\hline \multirow[t]{2}{*}{ Glycinin } & Acidic & 22.5 & 21.4 & 21.6 & 21.4 & 22.3 & 24.2 & 23.6 & 23.8 & 24.6 & 26.9 & 21.2 & 20.7 & 20.1 & 19.9 & 19.9 \\
\hline & Basic & 16.7 & 16.3 & 16.1 & 16.1 & 16.5 & 17.6 & 17.3 & 17.4 & 17.9 & 18.4 & 15.6 & 15.0 & 14.7 & 14.7 & 14.6 \\
\hline
\end{tabular}

A: Soybean, B: Extruded soybean, C: Soybean irradiated with dose $15 \mathrm{kGy}$, D: Soybean irradiated with dose $30 \mathrm{kGy}$, E: Soybean irradiated with dose 45 kGy, F: Sprouted soybean, G: Extruded sprouted soybean, H: Sprouted soybean irradiated with dose 15 kGy, I: Sprouted soybean irradiated with dose $30 \mathrm{kGy}$, J: Sprouted soybean irradiated with dose 45 kGy, K: Soybean meal, L: Extruded soybean meal, M: Soybean meal irradiated with dose $15 \mathrm{kGy}$, N: Soybean meal irradiated with dose $30 \mathrm{kGy}$, O: Soybean meal irradiated with dose $45 \mathrm{kGy}$.

The evidence for aggregation occurring in SB, SSB and EBM proteins through irradiation and extrusion were monitored by electrophoresis technique as shown in Fig 1. According to the running gel, accumulated proteins were observed as bands, which were narrow in the samples. These bands were thicker and sharper in irradiated samples than in the raw and extruded samples. Also, differences were observed for irradiated samples bands or protein subunits patterns in the middle of the gel.

Sprouts are a great source of vitamins and minerals which are produced from the seeds during the process of sprouting and their nutritional value is higher than the seeds themselves. During the process of sprouting, starch, protein, and fats of the seed are decomposed and are converted into lighter, more digestible and more absorbable materials. In this process, the amount of the vitamin, minerals, and protein of the seed increases, however; the amount of the calorie and carbohydrate reduces (Moghaddam, 2016). These changes may lead the bird to consume more willingly. By the beginning of sprouting, some changes occur in the nutritional value of the seeds. For instance, the chemical changes increase the amount of protein in the seeds (40.62 compared to 37.72 for sprouted soybeans and soy seeds, respectively). The reason for this increase is the activation and an increase of some enzymes as a result of sprouting for breaking and using starch and macromolecules for providing the energy needed for sprouting. These enzymes are proteins and that is why they increase the amount of protein. Kjaer and Hansen (2007) reported that birds fed with wheat sprout were more active than the control group. Previously indicate that the chemical composition of sprouted wheat may not be different from normal grains. Also, metabolizable energy was significantly higher for combinations of sprouted and normal wheat than for either wheat when fed alone. Sprouted soybean can be successfully used in rations for poultry during early chick growth. Calzuola et al. (2004) stated that sprouted wheat contains high amount of antioxidants (reducing chemicals), among others ascorbic acid. Processing by extrusion increased the amount of protein and reduced MWs of protein subunits. The reason was that during extrusion, anti-nutritional factors including inhibitors of trypsin, kimotripsin, and phytohemagglutinin, lipase and lipoxygenase are reduced up to 85 percent (Siddhuraju et al., 2002). Improvement in the quality of protein in soybean was reported as a result of the removal of trypsin and hemagglutinin inhibitors by irradiation processing. According to another report, phytic acid, alpha-amylase and oligosaccharides inhibitors were significantly reduced as a result of irradiation of legumes (Cheftel et al., 1985).

Irradiated feeds had more crude protein and less MW than the control treatment because the gamma irradiation causes oxidative stress and bimolecular effects through conformational changes, oxidation, and rupture of covalent bonds and the formation of free radicals (Halliwell and Gutteridge, 1989). Hydroxyl $(\mathrm{HO} \cdot)$ and superoxide anion $\left(\mathrm{O}_{2}{ }^{-}\right)$are radicals that are produced by irradiation and can improve molecular qualities of proteins and lipids. They can also cause the oxidative modification, per oxidation of proteins and fats (Cho and Song, 2000). The gamma irradiation causes chemical changes in the protein. These include fragmentation, interaction, formation and oxidation, which are created by oxygen radicals produced through water radiology (Wolff et al., 1986).

The gamma irradiation usually creates irreversible changes at the molecular surface by breaking the covalent bonds polypeptide chain. Maire et al. (1990) suggested that the breakpoints created by radiation in proteins are weak links in the polypeptide chain, although the radiation level plays an important role in creating breakpoints, too. According to the above topic and the results this study, it can be seen that $15 \mathrm{kGy}$ of irradiation created best breakpoints compared to other doses ( 30 and $45 \mathrm{kGy}$ ), while the dose of $30 \mathrm{kGy}$ provided good results compared to the control. Wolf et al., (1986) reported that peptide bonds can be split by the direct oxidation of proline residues resulting from radiation. This creates an autocatalist state in which products of radiation can accelerate the process of breaking the peptide bonds.

The experiments by Moon and Song (2001) showed that gamma irradiation affected the third building protein by changing tryptophan and tyrosine 

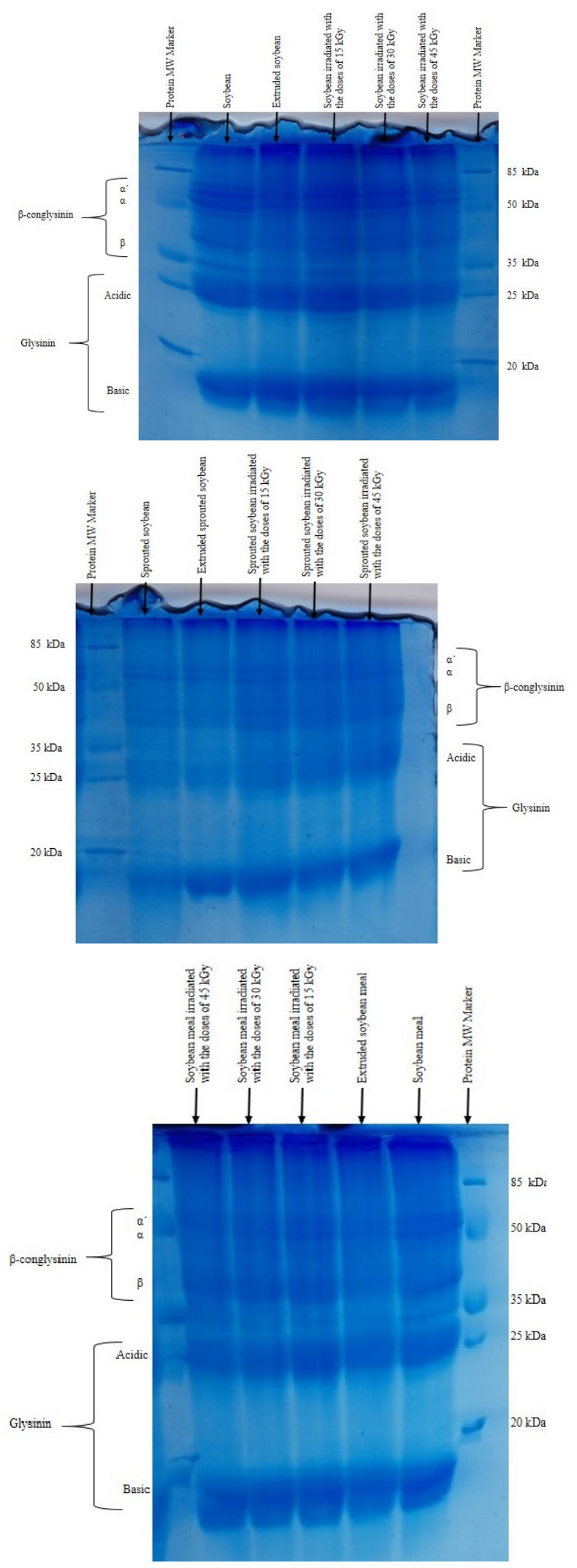

Fig. 1: Electrophoretic patterns of soybean (left), sprouted soybean (middle) and soybean meal (right) residues. The processing of soaked soybeans with gamma rays reduced phytic acid levels compared to untreated soybeans (Sattar et al., 1990). This decrease is probably due to the chemical decomposition of phytate for reducing inositol phosphates and inositol through the activity of free radicals produced by gamma radiation (Garrison, 1978). Another possible solution for reducing phytate during radiation could be related to the gap in the rings of phytate which led to an increase in crude protein in this experiment.

There are a lot of hydrophobic amino acids in the protein molecule in the inseparable structure of spherical proteins. Ionic radiation can increase the flexibility and denaturation of protein, reveals the level of the nonpolar groups that were previously closed, and increase the hydrophobicity of the molecule (Shawrang et al., 2013a). This is an acceptable situation for proteins to be close to each other and form a group (Shawrang et al., 2013b). There are evidences for the existence of these reactions by electrophoresis technique (Sato et al., 1969).

The effects of radiation on protein subunits using electrophoresis techniques shows that radiation causes the adhesion of protein and the formation of spots in the beginning of the gel (Liu et al., 2009). However, there were no stains on non-irradiated samples. In addition, many uncharacterized proteins were found from the analysis, which showed that irradiation modified proteins randomly with mainly scission. Alteration in electrophoretic patterns of egg white by gamma irradiation was reported previously (Shawrang et al., 2013b). Liu et al. (2009) showed that irradiation caused agglomeration as well as breakdown when different doses of irradiation were applied. They indicated that irradiation modified proteins mainly with scission.

\section{Conclusion}

The present study reveals that irradiation has no effect on the chemical composition of SB, SSB and EBM, but extrusion increased CP content. Considering that gamma irradiation and extrusion are appropriate methods for improving the nutritional value using the above processing methods as the physical processing methods can reduce anti-nutritional materials and increase the nutritional value and digestibility of the feed material through changes in the structure of the protein and starch in poultry feed. The reduction of the anti-nutritional materials and the increase of the nutritional value of the feed will eventually reduce the cost of feed and treatment, and will cause a considerable decrease in losses. The knowledge of the physical and chemical properties of protein and starch of feeds allows helping to increase the quality of feed processing. Valuable information about the effects of gamma irradiation and extrusion on the quality protein feed can be obtained by means of electrophoresis (SDS- 
PAGE). The extruded treatment has the highest amount of the crude protein, however; the MWs of its protein subunits is more than the soybean processed with a dose of $15 \mathrm{kGy}$ of gamma irradiation. Thus, from the above discussion, it can be concluded that $15 \mathrm{kGy}$ radiation dose will have the best impact. In conclusion, the dose of $15 \mathrm{kGy}$ irradiation caused mainly scission of proteins, which provided feed white structure with improved digesting ability. Thus, irradiation and extrusion can improve the quality of poultry feed products.

\section{References}

AOAC (2000) Official Methods of Analysis. 13th Ed. Association of Official Analytical Chemists, Arlington, VA.

Ayadi F, Muthukumarappan YK, Rosentrater KA, Brown ML (2011) Twin-Screw extrusion processing of rainbow trout (Oncorhynchus mykiss) feeds using various levels of corn based distillers dried grains with solubles (DDGS). Cereal Chem 88: 363-374.

Calzuola I, Marsili V, Gianfranceschi GL (2004) Synthesis of antioxidants in wheat sprouts. J. Agric. Food Chem 52: 5201-5206.

Cheftel JC, Cuq JL, Lorient D (1985) Amino acids, peptides, proteins. In: Fennema, OR, (Ed.), Food Chemistry, New York: Marcel Dekker, p. 80.

Cho Y, Song KB (2000) Effect of $\gamma$-irradiation on the molecular properties of BSA and $\beta$-lactoglobulin. $\mathbf{J}$ Biochem Mol Biol 33: 133-137.

Davies H (1998) Manufacturing of full-fat soybeans.1998. Workshop: Processing of full-fat soya. Irene, South Africa, Proceedings, pp: 21-23.

Duncan DB (1955) Multiple range and Multiple F test. Biometrics 11:1.

Fallahi P, Rosentrater KA, Muthukumarappan K, Tulbek M (2013) Effects of steam, moisture, and screw speed on physical properties of DDGS-based extrudates. Cereal Chem 90: 186-197.

Garrison WM (1978) Reaction mechanism in the radiolysis of peptides, polypeptides, and proteins. Food Chem 87: 381-398.

Halliwell B, Gutteridge JMC (1989) Free radicals in Biology and Medicine, Oxford: Science Publications, p: 45.

Kjaer JB, Hansen BK (2007) Effect of supplemental roughage on behavior, physiological stress response, and egg production parameters of farmed partridges (Perdix perdix). Poult Sci 86: 16401645.

Liu XD, Han RX, Yun H, Jung KC, Jin DI, Lee BD, Min TS, Jo C (2009) Effect of irradiation on foaming properties of egg white proteins. Poult Sci 88: $2435-2441$.
Maire Mle, Thauvette L, De Foresta B, Viel A, Beauregard G, Potier M (1990) Effects of ionizing radiations on proteins. Biochem J 267: 431-439.

Moghaddam M (2016) Effects of Gamma Irradiation and Extrusion Process on Molecular Morphology of Starch and Protein, and Ileal Amino Acids Digestibility of Soybean, Corn and Sorghum in Broilers. Ph.D Thesis, Animal Feed Science, Islamic Azad University of Science and Research Branch, Tehran, Iran.

Moon S, Song KB (2001) Effect of gamma irradiation on the molecular properties of ovalbumin and ovomucoid and protection by ascorbic acid. Food Chem 74: 479-483.

Oryschak M, Korver D, Zuidhof M, Beltranena E (2010) Nutritive value of single-screw extruded and nonextruded triticale distillers dried grains with solubles, with and without an enzyme complex, for broilers. Poult Sci 89: 1411-1423.

Sadeghi AA, Nikkhah A, Shawrang P, Shahrebabak MM (2006) Protein degradation kinetics of untreated and treated soybean meal using SDSPAGE. Anim Feed Sci Technol 126: 121-133.

Sadeghi AA, Shawrang P (2008) Effects of microwave irradiation on ruminal dry matter, protein and starch degradation characteristics of barley grain. Anim Feed Sci Technol 141: 184-194.

SAS Institute. SAS® (Statistical Analysis System) version 9.3.2004. User's Guide: Statistics. Cary, NC: SAS Institute Inc.

Sato Y, Umenoto Y, Kume T (1969) The effect of gamma irradiation on egg white proteins. Preliminary report. Jap Food Irrad 4: 42-46.

Sattar A, Neelofar X, Akhtar MA (1990) Irradiation and germination effects on phytate, protein and amino acids of soybean. Plant Foods Hum Nutr 40: 185-194.

Shawrang P, Sadeghi AA, Ghorbani B (2013a) The effect of electron beam irradiation on $\beta$-glucan content, X-ray diffraction of starch, protein subunit patterns, and in vivo digestibility of barley grain in cockerels. Turk J Vet Anim Sci 37: 443-448.

Shawrang P, Nikkhah A, Zare-Shahneh A, Sadeghi AA, Raisali G, Moradi-Shahrebabak M (2013b) Effects of gamma irradiation on protein degradation of soybean meal in the rumen. Anim Feed Sci Technol 134: 140-151.

Shawrang P, Sadeghi AA, Behgar M, Zareshahi H, Shahhoseini G (2011) Study of chemical compositions, antinutritional contents and digestibility of electron beam irradiated sorghum grains. Food Chem 125: 376-379.

Siddhuraju P, Makkar HPS, Becker K (2002) The effect of ionizing radiation on antinutritional factors and the nutritional value of plant materials with reference to human and animal food. Food Chem 78: 187-205. 
Taghinejad M, Nikkhah A, Sadeghi A, Raisali G, Chamani M (2009) Effects of gamma irradiation on chemical composition, antinutritional factors, ruminal degradation and in vitro protein digestibility of full-fat soybean. Asian-Aust J Anim Sci, 22(4): 534-541.

Taghinejad-Roudbaneh M, Ebrahimi SR, Azizi S, Shawrang P (2010) Effects of electron beam irradiation on chemical composition, antinutritional factors, ruminal degradation and in vitro protein digestibility of canola meal. Rad Phys Chem 107: 264-1269.
Van Soest PJ, Robertson JB, Lewis BA (1991) Methods for dietary fiber, neutral detergent fiber and nonstarch polysaccharides in relation to animal nutrition. J Dairy Sci 74:3583-3597.

Variyar PS, Limaye A and Sharma A (2004) RadiationInduced Enhancement of Antioxidant Contents of Soybean (Glycine max Merrill). J Agric Food Chem 52: 3385-3388.

Wolff SP, Garner A, Dean RT (1986) Free radicals, lipids and protein degradation. Trends Biochem Sci 11: 27-31. 